Tohoku J. Exper. Med., 1962, 78, 202-208

\title{
Glomus Tumor of the Stomach
}

\author{
By \\ Shoichi Yamagata \\ Medical Department of Prof. S. Y a magata, Tohoku \\ University School of Medicine, Sendai \\ Tadami Shoji, Satoshi Kawashima, Toshiki Narasaka \\ Susumu Sato, and Motoshi Kawamura \\ Hanamaki Foundation Hospital of Dr. T. Sato, \\ Hanamaki City, Iwate Prefecture \\ Naoya Matoba \\ Surgical Clinic of Prof. S.-T. Kats ura, Tohoku University School \\ of Medicine, Sendai \\ Haruki Wakasa \\ Department of Pathology of Prof. K. Akazaki, Tohoku \\ University School of Medicine, Sendai
}

(Received for pulication, September 19, 1962)

Though there have been many reports of glomus tumors arising from the subcutaneous tissues of the extremities, reports of glomus tumor originating from other organs are rather rare. Glomus tumor of the stomach was described by Kay et al. ${ }^{1)}$ for the first time in 1951 and more than 10 cases $^{2-9}$ which have appeared since then have been gathered from various sources for this paper.

With the progress of diagnostic measures for gastrointestinal diseases, it has become fairly easy to make and early diagnosis of stomach tumors.

This is a case report of a young woman who was found by X-ray examination and gastrocamera to have a small polyp of the stomach wall and who was finally diagnosed as having glomus tumor of the stomach by histological examination. The previously reported cases are also reviewed.

\section{CASE REPORT}

The patient was a 29-year-old female, who had developed vomiting, diarrhea, 
weakness, mild fever, and fatigue for two months previous to examination. One month prior to admission, she had sought hospitalization for pyrosis and colicky pain in the right upper quadrant.

Physical examination revealed that she was a well nourished female in no acute distress. Her temperature was $36.7^{\circ} \mathrm{C}$; pulse was normal; blood pressure was $112 / 76 \mathrm{~mm} \mathrm{Hg}$; tonsils were slightly enlarged, but not reddish; and her heart was not enlarged to percussion. No rales were heard in the lungs, and though there was a slight tenderness in the right side of the umbilicus, no tumor was palpable. The liver, spleen, and kidneys were not swollen, but edema was noted on the lower extremities.

Laboratory data: Urineanalysis was negative. Occult blood in the feces was negative. The WBC was 6,400 and the $\mathrm{RBC}$ was $413 \times 10^{4}$, hemoglobin was $76 \%$ (Sahli's method), and its index was 0.92 . The liver function test was normal. The erythrocyte segmentation rate was slightly elevated. An electrocardiogram showed no abnormality, but gastric juice (Katsch-Kalk's method) showed anacidity. A roentogenogram of the stomach showed a round translucent area on the lesser curvature in the back wall of the antrum. It was considered that the lesion in the stomach was as a polyp, however, this tumor was not movable and no pain by pressure was noted. Slight pain was present in the duodenal bulb, but no abnormality was seen. The film from the gastrocamera revealed no abnormal findings, but a half rounded tumor covered by normal mucosa was seen.

Findings upon operation: Using closed circulatory anesthesia, a laparotomy was performed, but no ascites or adhesions were seen in the abdominal cavity. A circumscribed elastic tumor about $8 \times 7 \mathrm{~mm}$ was observed on the lesser curvature in the back wall of the antrum and the pyloric sphincter muscle was hypertrophied. A stomach resection and gastroduodenostomy were performed according to Billroth 1 . The tumor which lay within the muscularis propria was partially encapsulated by the surrounding tissues. The surface of the tumor was smooth and overlayed with a dark red and brownish fluid, so that its appearance was similar to hemangioma. Upon cutting into the surface of the tumor, however, a parenchymatous and grayish substance appeared, it was not bloody.

Histological findings: The tumor was partially encapsulated and was composed of sheets and cords of uniform cells, having nuclei which stained round and dark with an abundance of clear cytoplasm. The cell borders were observed in some places. The tissue of the tumor was very vascular having numerous capillaries which were lined with flat endothelia and a substance taking a reddish stain which could be seen in the lumina. In the surrounding muscularis, the vascular spaces were dilated and similar cell groups were found in some places around the vessels. Using Gomori's silver impregnation technique, a marked abundance of fine fibers of reticulin could be seen, and these sometimes separated 
the tumor cells into small groups. The presence of argyrophilic granules in the tumor could not be demonstrated in a section prepared by Bodian's \& Fontana's silver impregnation technique.

\section{COMMENT}

It is said that glomus tumor arises from the neuro-myo-arterial glomera named by Masson in 1935. This glomera consists of vascular spaces and round cells (i. e. glomus cells) and it regulates the motion and the temperature of the blood vessels.

In general, the tumors are found in the subcutaneous tissues. The tumors are generally encapsulated and are considered to be benign in nature.

However, a glomus tumor originating from the stomach is very rare because the presence of glomera in the stomach is questionable.

In 1948, Murray \& Stout ${ }^{10)}$ gathered data on 240 cases of glomus tumor and investigated the origin of these tumors. They stated that it was possible for tumors to appear in those internal organs where the glomera cannot normally be found. Moreover, tissue culture of the tumors revealed that the glomus cells were the same as the pericytes of Zimmermann, so it is possible for glomus tumors to arise in any organ in which there are pericytes.

Previous reported cases of glomus tumor gathered from various sources are summarized in Table I, but it is presumed that there have been other cases

Table I. Data on Glomus Tumor of the Stomach

\begin{tabular}{|c|c|c|c|c|c|c|c|c|}
\hline No. & Author & Age & Sex & Symptoms & Bleeding & Location & Size & $\begin{array}{l}\text { With }(+) \text { or } \\
\text { without }(-) \\
\text { ulceration }\end{array}$ \\
\hline 1 & \multirow{3}{*}{$\begin{array}{l}\text { Kay et } \\
\quad \text { al. } 1951\end{array}$} & 50 & 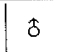 & Obstruction & none & Pylorus & $10 \times 6 \mathrm{~mm}$ & $(-)$ \\
\hline 2 & & 43 & $\delta$ & $\begin{array}{l}\text { Nausea, } \\
\quad \text { Vomiting }\end{array}$ & $\begin{array}{l}\text { Shock } \\
\text { hematemesis }\end{array}$ & $\begin{array}{c}\text { Anterior } \\
\text { portion of } \\
\text { pylorus }\end{array}$ & $\begin{array}{l}3 \times 2 \\
5 \times 4 \mathrm{~mm}\end{array}$ & $(+)$ \\
\hline 3 & & 46 & $\delta$ & $\begin{array}{l}\text { Melena for } \\
3 \text { years after } \\
\text { typhoid }\end{array}$ & none & $\begin{array}{l}\text { Posterior } \\
\text { pyloric } \\
\text { wall }\end{array}$ & $\begin{array}{l}3 \mathrm{~cm} \\
\text { diameter }\end{array}$ & $(+)$ \\
\hline 4 & $\begin{array}{r}\text { Spangler } \\
1953\end{array}$ & 67 & $\delta$ & & none & Antrum & & $(-)$ \\
\hline 5 & \multirow{2}{*}{$\begin{array}{l}\text { Allen \& } \\
\text { Dahlin } \\
1954\end{array}$} & 47 & 우 & & Syncope: & $\left|\begin{array}{c}5 \mathrm{~cm} \text {. proximal } \\
\text { to pylorus on } \\
\text { greater } \\
\text { curvature }\end{array}\right|$ & $\begin{array}{l}2.5 \mathrm{~cm} \\
\text { diameter }\end{array}$ & $(+)$ \\
\hline 6 & & 42 & $\hat{o}$ & $\begin{array}{l}\text { Irregular } \\
\text { intermittent } \\
\text { abdominal } \\
\quad \text { pains }\end{array}$ & & $\begin{array}{l}\text { Level of } \\
\text { angle. lesser } \\
\text { curvature }\end{array}$ & $2.5 \mathrm{~cm}$. & $(-)$ \\
\hline
\end{tabular}




\begin{tabular}{|c|c|c|c|c|c|c|c|c|}
\hline 7 & $\begin{array}{l}\text { Mannix et } \\
\text { al. } 1955\end{array}$ & 53 & $\delta$ & $\begin{array}{l}\text { Anorexia: } \\
\text { heartburn }\end{array}$ & $\begin{array}{l}\text { Syncope: } \\
\text { hematemesis }\end{array}$ & $\begin{array}{r}\text { Prepyloric } \\
\text { area greater } \\
\text { curvature }\end{array}$ & $34 \times 12 \mathrm{~mm}$ & $(+)$ \\
\hline 8 & $\begin{array}{l}\text { Shocket et } \\
\text { al. } 1957\end{array}$ & 65 & $\delta$ & $\begin{array}{l}\text { Fatty food } \\
\text { intolerance: } \\
\text { weightloss, } \\
\text { constipation }\end{array}$ & Normal stools & $\begin{array}{l}\text { Antrum } \\
\text { greater } \\
\text { curvature }\end{array}$ & $2 \times 3 \times 2 \mathrm{~mm}$ & $(-)$ \\
\hline 9 & $\begin{array}{l}\text { Donovan } \\
\text { et al. } 1958\end{array}$ & 67 & f & $\begin{array}{c}\text { Attacks of } \\
\text { nausea, } \\
\text { vomiting }\end{array}$ & none & $\begin{array}{c}\text { Antrum, } \\
\text { greater } \\
\text { curvature }\end{array}$ & $3 \times 2.5 \mathrm{~cm}$ & $(-)$ \\
\hline 10 & Arge 1960 & 73 & q & $\begin{array}{l}\text { Colicky pain } \\
\text { of gallstones }\end{array}$ & none & $\begin{array}{l}\text { Antrum, } \\
\text { greater } \\
\text { curvature }\end{array}$ & & $(-)$ \\
\hline 11 & $\begin{array}{l}\text { Shoji et } \\
\text { al. } 1962\end{array}$ & 29 & q & $\begin{array}{r}\text { Vomiting, } \\
\text { diarrhea, } \\
\text { weakness }\end{array}$ & Normal stools & $\begin{array}{l}\text { Antrum, } \\
\text { lesser } \\
\text { curvature }\end{array}$ & $8 \times 7 \mathrm{~mm}$ & $(-)$ \\
\hline 12 & $\begin{array}{c}\text { Takahashi } \\
\& \\
\text { Numakura } \\
1962\end{array}$ & 30 & ㅇ & $\begin{array}{l}\text { Abdominal } \\
\text { pain, nausea, } \\
\text { vomiting }\end{array}$ & none & $\begin{array}{l}\text { Antrum, } \\
\text { greater } \\
\text { curvature }\end{array}$ & $\begin{array}{r}2.5 \times 2.5 \\
\times 2 \mathrm{~cm}\end{array}$ & $(-)$ \\
\hline
\end{tabular}

which have not come to light. Some features of glomus tumor are as follows:

1) Origin of the tumors: The tumors arise chiefly in the muscularis of the prepyloric area of the stomach and the growth of the tumors causes ulceration, in which case bleeding may occur. Ulceration caused by the tumor was seen in 4 cases and resultant shock was reported in 3 cases.

2) Symptoms: There are no specific clinical signs. First symptoms are manifest as uncertain gastrointestinal disorders and the tumor may appear in a roentogenograph as a polyp.

3) Prognosis: Most of the tumors are encapsulated and it is possible to remove them completely by operation, so prognosis is usually good.

4) Differential diagnosis: It is necessary to differentiate this tumor from carcinoid. In practice, most of the cases reported here had been diagnosed clinically as carcinoid and they were revealed to be glomus tumor only by histological investigation. The chief point of differential diagnosis between glomus tumor and carcinoid is that the former shows a vascular pattern and a negative reaction in Bodian's silver impregnation. Bodian's reaction in our case was negative.

It is apparent that this tumor may cause severe gastrointestinal bleeding and consequent shock, so early diagnosis of the tumor (the possibility of polyp) is important.

\section{SUMMARY}

This paper reports on a case of glomus tumor, and its clinicopathological 
features as gathered from various sources are reveiwed.

\section{References}

1) Kay, S. et al., Cancer, 1951, 4, 726.

2) Spangler, H., Chirurg., 1953, 24, 181.

3) Allen, R.A. \& Dahlin, D.C., Proc. Staff Meet. Mayo Clin., 1954, 29, 429.

4) Mannix, A.J. et al., Surgery, 1955, 37, 473.

5) Schoket, E. et al., Gastroenterology, 1957, 32, 1145.

6) Donovan, R.J. et al., J. Intern. College Surgeons, 1958, 29, 699.

7) Arge, E., Acta Path. et Microb. Scand., 1960, 48, 197.

8) Shoji, T. et al., Tohoku Ishi (Jap.), 1962, 65, 248.

9) Takahashi, K. \& Numakura, M., Japanese J. Cancer Clin. (Jap.), 1962, 8, 335.

10) Murray, M. R. \& Stout, A.P., Amer. J. Path., 1942, 18, 183. 
Fig. 1. A roentogenogram of the stomach: Filling defect in the antrum along the lesser curvature is observed.
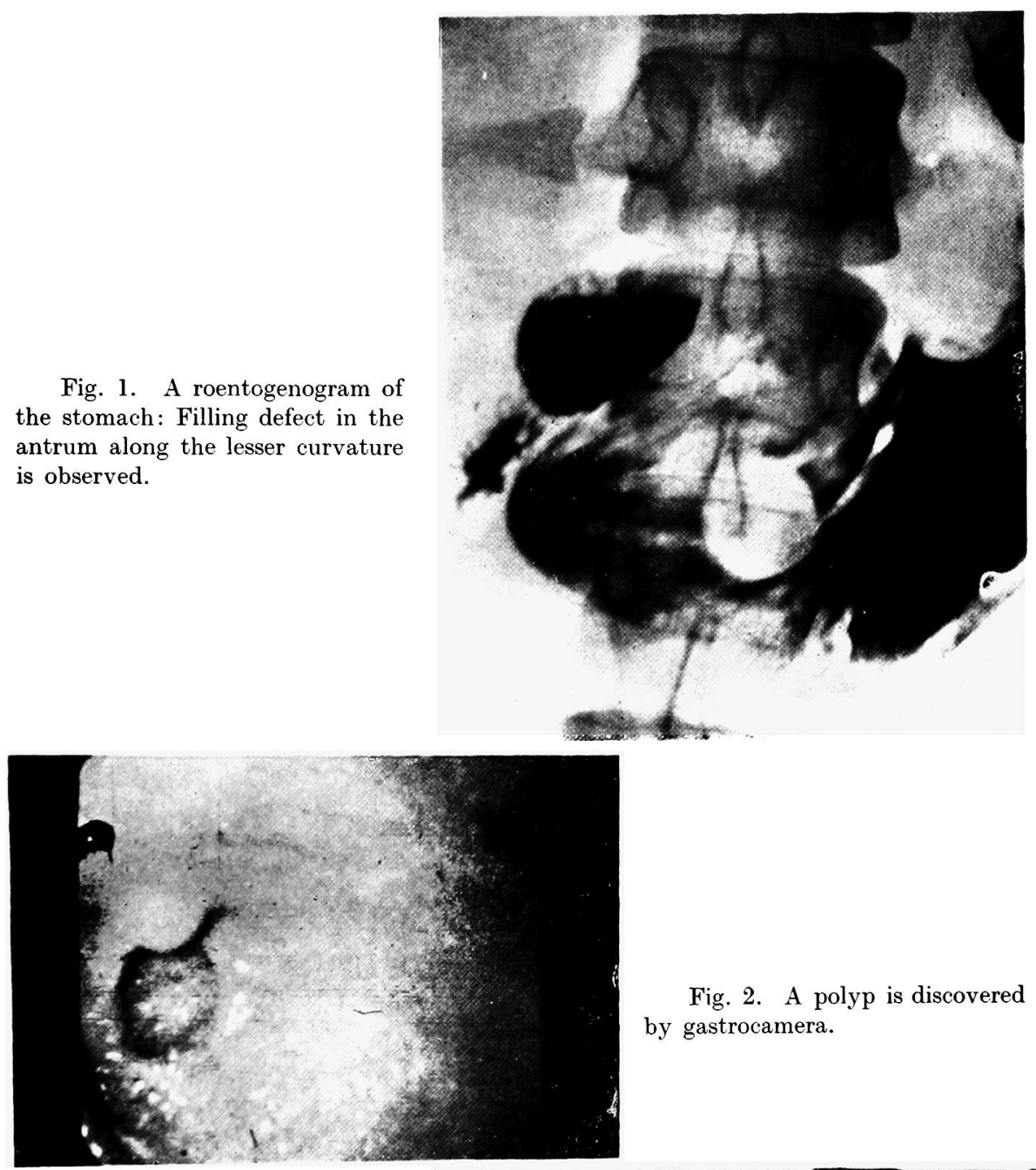

Fig. 2. A polyp is discovered by gastrocamera.

Fig. 3. Internal surface of the stomach after operation.

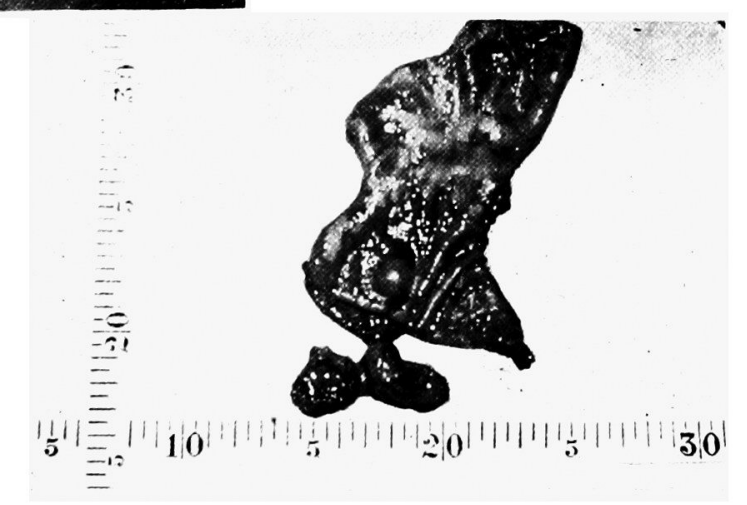




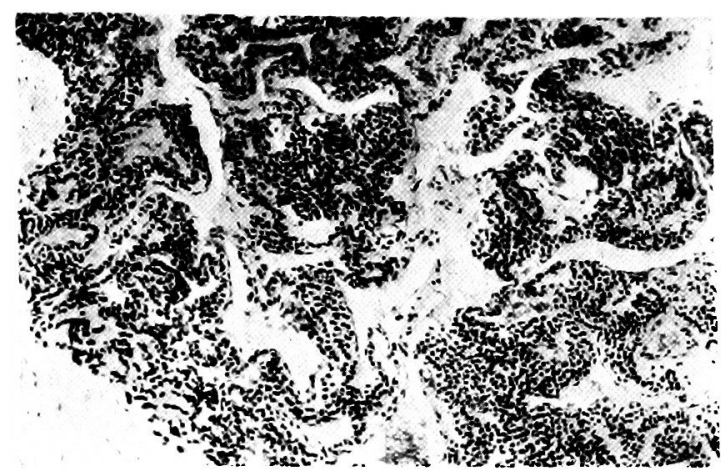

Fig. 4. Histological appearance of the tumor:

Vascular spaces and sheet or cordlike arrangement of glomus cells are seen.

(H.E. $\times 100)$

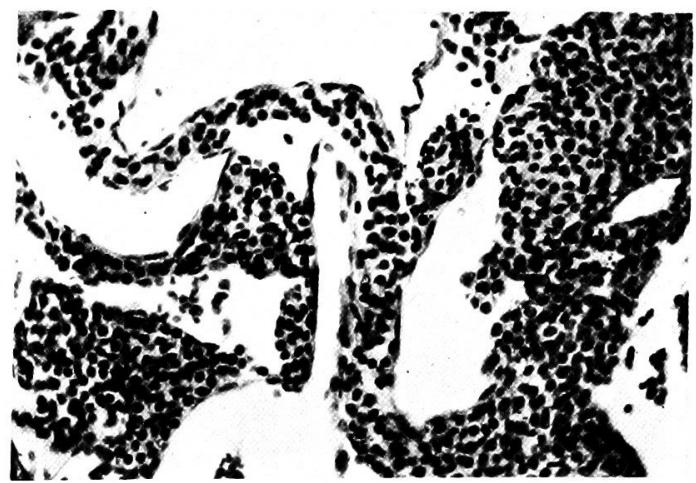

Fig. 5. High magnification of the tumor:

Vascular spaces are lined with flat endothelia.

(H.E. $\times 250)$

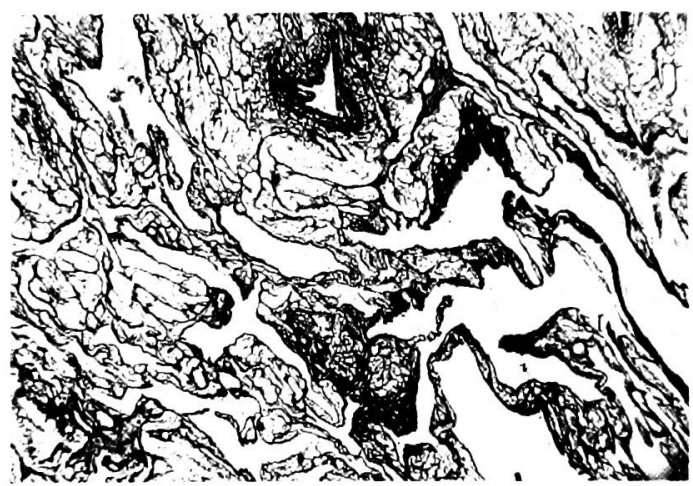

Fig. 6. Silver impregnation of the tumor:

Fine reticulin fibers are marked and they surround tumor cells. (Gomori's technique $\times 100$ ) 